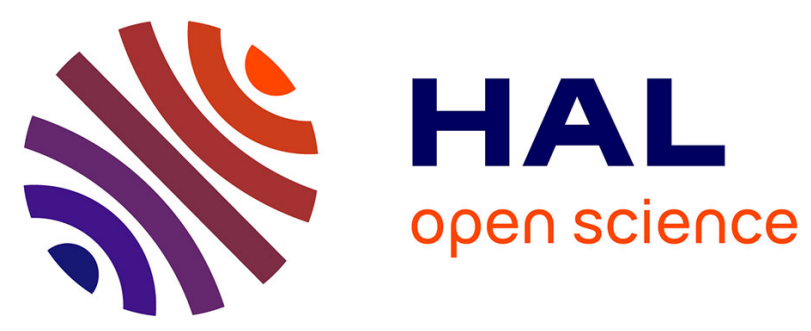

\title{
Prevention of Marine Biofouling Using the Natural Allelopathic Compound Batatasin-Ill and Synthetic Analogues
}

Lindon W. K. Moodie, Rozenn Trepos, Gunnar Cervin, Kari Anne Brathen, Bente Lindgard, Rigmor Reiersen, Patrick Cahil, Henrik Pavia, Claire Hellio, Johan Svenson

\section{To cite this version:}

Lindon W. K. Moodie, Rozenn Trepos, Gunnar Cervin, Kari Anne Brathen, Bente Lindgard, et al.. Prevention of Marine Biofouling Using the Natural Allelopathic Compound Batatasin-Ill and Synthetic Analogues. Journal of Natural Products, 2017, 80 (7), pp.2001-2011. 10.1021/acs.jnatprod.7b00129 . hal-02611999

\section{HAL Id: hal-02611999 \\ https://hal.science/hal-02611999}

Submitted on 18 May 2020

HAL is a multi-disciplinary open access archive for the deposit and dissemination of scientific research documents, whether they are published or not. The documents may come from teaching and research institutions in France or abroad, or from public or private research centers.
L'archive ouverte pluridisciplinaire HAL, est destinée au dépôt et à la diffusion de documents scientifiques de niveau recherche, publiés ou non, émanant des établissements d'enseignement et de recherche français ou étrangers, des laboratoires publics ou privés. 


\section{Prevention of Marine Biofouling Using the Natural}

\section{Allelopathic Compound Batatasin-III and Synthetic}

\section{Analogues}

Lindon W. K. Moodie, ${ }^{\dagger, \# ~ R o z e n n ~ T r e p o s, ~}{ }^{\star}$ Gunnar Cervin, ${ }^{\S}$ Kari Anne Bråthen, ${ }^{\perp}$ Bente Lindgård, ${ }^{\perp}$ Rigmor Reiersen, ${ }^{\perp}$ Patrick Cahill, ${ }^{\|}$Henrik Pavia, ${ }^{\S}$ Claire Hellio ${ }^{\ddagger}$ and Johan Svenson ${ }^{*}+, \nabla$

'Department of Chemistry, UiT The Arctic University of Norway, Breivika, N-9037, Troms $\varnothing$, Norway

${ }^{\ddagger}$ Université de Bretagne Occidentale, Biodimar/LEMAR UMR 6539, rue Dumont d'Urville, 29280 Plouzané, France

${ }^{\S}$ Department of Marine Sciences - Tjärnö, University of Gothenburg, SE-452 96 Strömstad, Sweden

$\perp^{\perp}$ Department of Arctic and Marine Biology, UiT The Arctic University of Norway, Breivika, N-9037, Troms $\varnothing$, Norway

"Cawthron Institute, 98 Halifax St East, Nelson 7010, New Zealand

${ }^{\nabla}$ Department of Chemistry, Material and Surfaces, RISE Research Institutes of Sweden, Box 857, SE-501 15 Borås, Sweden 


\begin{abstract}
The current study reports the first comprehensive evaluation of a class of allelopathic terrestrial natural products as antifoulants in a marine setting. To investigate the antifouling potential of the natural dihydrostilbene scaffold, a library of 22 synthetic dihydrostilbenes with varying substitution patterns, many of which occur naturally in terrestrial plants, were prepared and assessed for their antifouling capacity. The compounds were evaluated in an extensive screen against 17 fouling marine organisms. The dihydrostilbene scaffold was shown to possess powerful general antifouling effects against both marine microfoulers and macrofoulers with inhibitory activities at low concentrations. The species of microalgae examined displayed a particular sensitivity towards the evaluated compounds at low $\mathrm{ng} / \mathrm{mL}$ concentrations. It was shown that several of the natural and synthetic compounds exerted their repelling activities via non-toxic and reversible mechanisms. The activities of the most active compounds such as 3,5-dimethoxybibenzyl (5), 3,4-dimethoxybibenzyl (9) and 3-hydroxy3',4,5'-trimethoxybibenzyl (20) were comparable to the commercial antifouling booster biocide Sea-nine ${ }^{\mathbf{r M}}$, which was employed as a positive control. The investigation of terrestrial allelopathic natural products to counter marine fouling represents a novel strategy for the design of "green" antifouling technologies and these compounds offer a potential alternative to traditional biocidal antifoulants.
\end{abstract}


Some species of terrestrial plants accumulate secondary metabolites that negatively affect other plants growing nearby. ${ }^{1}$ These compounds, known as allelopathic phytochemicals, can direct plant community composition and development. ${ }^{1-3}$ For example, some allelochemicals diffuse into the surrounding soil, either directly from the live plants or passively via degradation of dead plants, to suppress seedling growth and germination. In doing so, allelochemicals can prevent the establishment of other plant species that could otherwise compete for space or resources. ${ }^{3,4}$

Many phytochemicals, such as the flavonoids, lignans, proanthocyanidins, phenolic acids and stilbenes, are secondary metabolites where the phenolic functionality is highly represented. ${ }^{5,6}$ The roles of these phytochemicals are diverse but are often associated with plant defense, either against grazers, microorganisms or competing plant species via allelopathic routes. ${ }^{7,8}$ One such allelopathic phytochemical is the reduced stilbene derivative 3,3'-dihydroxy-5-methoxydibenzyl commonly known as batatasin-III (1). Compound $\mathbf{1}$ was first reported in the bulbils of Dioscorea batatas (yam tubers) and has since been shown to be present in many species of orchid (family Orchidaceae). ${ }^{9-11}$ The Arctic and circumboreal evergreen dwarf shrub Empetrum nigrum (crowberry, shown in Figure S1 in Supporting Information) is likewise a prolific producer of $\mathbf{1}$. As much as $6 \%$ of the dry leaf weight of $E$. nigrum consists of $\mathbf{1}$, and it has been shown to accumulate in the surrounding soil where it negatively influences the establishment of new individuals of both tundra plants and trees via allelopathic mechanims..$^{3,12,13}$

Terrestrial plants are not the only taxa to produce allelochemicals. A range of marine organisms produce allelochemicals, with sessile biofouling organisms and planktonic microalgae providing particularly rich sources of these compounds. As with terrestrial plants, 
sessile biofouling organisms such as sponges ${ }^{14,15}$ and macroalgae $e^{16,17}$ are at risk of being overgrown or outcompeted by neighboring organisms. This often intense competition for space between sympatric organisms has given rise to an arsenal of allelopathic metabolites. ${ }^{14}$ Likewise, some planktonic microalgae form dense "blooms", using allelochemicals to suppress sympatric competitive species of microalgae. ${ }^{18,19}$

The use of the allelopathic naphthoquinone juglone from Juglans nigra (black walnut) to prevent surface colonization by marine microorganisms is an innovative example of the evaluation of a terrestrial allelochemical in a marine setting. ${ }^{20}$ The growth of organisms on marine surfaces is known as biofouling (shown in Figure S2 in Supporting Information) and rapidly occurs on materials and surfaces submerged in water. ${ }^{21}$ The biofouling film rapidly increases the weight and roughness of boats, buoys, and aquaculture equipment, leading to increased maintenance costs, damage to infrastructure and higher fuel usage. ${ }^{21,22}$ Historically, biofouling has been successfully combatted using paints that incorporate biocides, particularly the organotin compound tributyl tin (TBT). ${ }^{23}$ However, these biocides have had a range of negative effects on the marine environment due to their non-specific modes of action and high potency; in the case of TBT down to $1 \mathrm{ng} / \mathrm{L}$. Accordingly, the International Maritime Organization implemented a worldwide ban on TBT in 2003, and all other general biocides were banned from use in $2008 .^{21,24}$

Marine natural compounds are currently being investigated as potential antifoulants, aiming for a lower environmental impact and ideally a repelling or deterring mode of action. ${ }^{25,26}$ Several highly active natural antifoulants have been reported. ${ }^{27}$ Butenolide produced by a marine Streptomyces strain, is currently being developed towards a commercial product. ${ }^{28}$ The biofouling community is composed of both microfoulers (bacteria and microalgae) and the 
larger macrofoulers (for example, bivalves, ascidians, macroalgae, tubeworms, and barnacles). Being able to screen potential antifouling agents against all these representative organisms increases the chances of discovering leads for further development. ${ }^{29,30}$

The established allelopathic effect and capacity of $\mathbf{1}$ inspired us to investigate if these effects are transferable to a marine setting. Although it seems $\mathbf{1}$ has less capacity to interfere with the direct growth of Lactuca sativa roots $\left(\mathrm{IC}_{50}\right.$ at $\left.1-2 \mathrm{mM}^{13}\right)$ compared to that of juglone $\left(\mathrm{IC}_{50}\right.$ at $0.075-0.15 \mathrm{mM},{ }^{31}$ merismatic activity), the structurally simple dibenzylic dihydrostilbene scaffold of $\mathbf{1}$ serves as a practical entry point to a library of analogues for evaluation. Vegetable tannins have been shown to display a reversible narcotic effect on Balanus amphitrite illustrating that phenolic natural compounds can possess interesting antifouling properties. ${ }^{32,33}$ To investigate the antifouling potential of the natural dihydrostilbene scaffold, a library of 22 synthetic dihydrostilbenes with varying substitution patterns were prepared and evaluated in an extensive screen against 17 different organisms. The compounds were screened initially against lettuce seedling (representative for many seed plants ${ }^{13}$ ) root growth before being exposed to ten different marine bacterial strains and four microalgal strains. Macrofouling was investigated by assessing the inhibition of the barnacle Balanus improvisus cyprid metamorphosis and also against the ascidian Ciona savignyi for selected compounds. The commercial antifouling booster biocide Sea-Nine $211^{\mathrm{TM}}$ (Dow) was included in the assays as a relevant positive control.

\section{RESULTS AND DISCUSSION}

Compound Library Design and Synthesis. The compound library was based on the dihydrostilbene scaffold of $\mathbf{1}$ and was designed to probe the contributions from both hydroxyl and methoxy substituents common in naturally occurring stilbenes. ${ }^{34}$ The library was 
composed of 22 dihydrostilbenes and was designed to contain compounds with a degree of substitution ranging from mono- to tetrasubstitution. The degree of substitution was also reflected in the polarity (calculated $\mathrm{C} \log \mathrm{P}$ ) of the compounds which ranged from 1.99 to 4.60 allowing for an evaluation of the impact of this physicochemical property on the biological activity. The compounds were assembled employing Wittig or Horner-Wadsworth-Emmons methodology, followed by hydrogenation, which are widely accepted methods for the production of substituted 1,2-diphenylethanes. ${ }^{35,36}$ Benzyl protection was employed for the hydroxy and methoxy groups were demethylated with $\mathrm{HBr} / \mathrm{AcOH}$.

\section{Scheme 1. General Synthetic Strategy for the Synthesis of Compounds 2-22 Employing either Wittig or Horner-Wadsworth-Emmons Methodology.}

\section{General dihydrostilbene synthetic route}

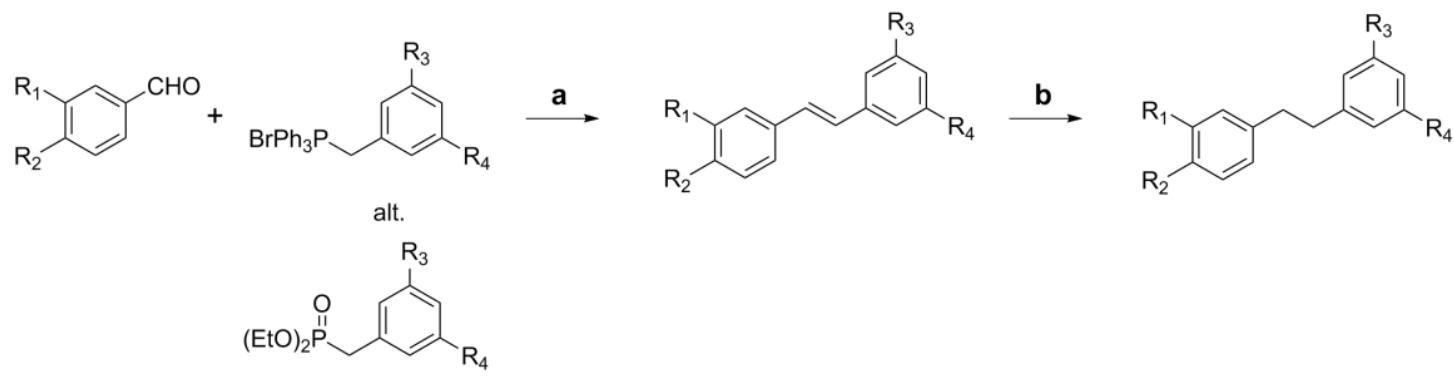

Example. Synthesis of compounds 12 and 10

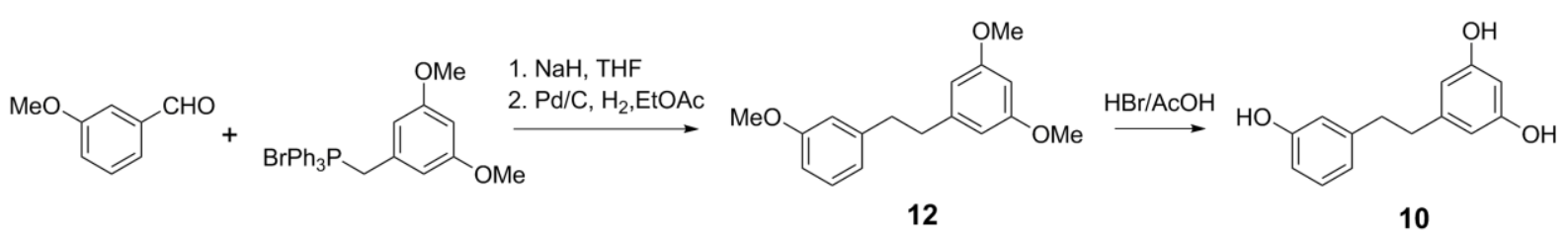

The methods employed were rapid and reliable and afforded the compounds in high yields. A recent study highlighted how bibenzyls can be readily accessed via $\mathrm{C}\left(\mathrm{sp}^{3}\right)-\mathrm{H}$ activation of methyl arenes under metal-free conditions, ${ }^{37}$ suggesting an effective yet benign "green" method to access these compounds in the future. The majority of the compounds prepared 
have been reported as natural products from terrestrial plant sources before (Table S1 in Supporting Information). Figure 1 presents the structures of the prepared compounds.<smiles>COc1cc(O)cc(CCc2cccc(O)c2)c1</smiles>

batatasin-III 1

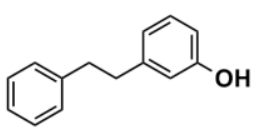

2<smiles>COc1cc(CCc2ccccc2)cc(OC)c1</smiles>

5

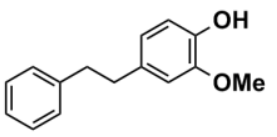

8<smiles>Oc1ccc(CCc2cc(O)cc(O)c2)cc1</smiles>

11<smiles>COc1cccc(CCc2cc(O)cc(OC)c2)c1</smiles>

14<smiles>Oc1cc(O)cc(CCc2ccc(O)c(O)c2)c1</smiles>

17<smiles>COc1cc(CCc2ccc(OC)c(O)c2)cc(OC)c1</smiles>

20

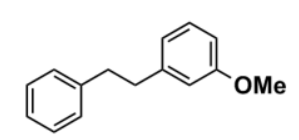

3<smiles>Oc1ccc(CCc2ccccc2)cc1O</smiles>

6

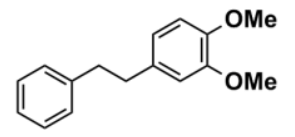

9<smiles>COc1cccc(CCc2cc(OC)cc(OC)c2)c1</smiles>

12<smiles>COc1cccc(CCc2cc(O)cc(O)c2)c1</smiles>

15<smiles>COc1cc(CCc2cc(O)cc(O)c2)ccc1O</smiles>

18<smiles>COc1cc(CCc2ccc(O)c(OC)c2)cc(OC)c1</smiles>

21<smiles>Oc1cc(O)cc(CCc2ccccc2)c1</smiles>

4<smiles>COc1ccc(CCc2ccccc2)cc1O</smiles>

7<smiles>Oc1cccc(CCc2cc(O)cc(O)c2)c1</smiles>

10<smiles>COc1ccc(CCc2cc(OC)cc(OC)c2)cc1</smiles>

13<smiles>COc1cc(O)cc(CCc2ccc(O)c(OC)c2)c1</smiles><smiles>COc1ccc(CCc2cc(O)cc(O)c2)cc1O</smiles>

19<smiles>COc1cc(CCc2ccc(OC)c(OC)c2)cc(OC)c1</smiles>

22

Figure 1. Structure of batatasin-III (1) and synthetic dihydrostilbene derivatives 2-22 included in the present study 
Inhibition of Lactuca sativa Seedling Roots. Recent studies on the effect of $\mathbf{1}$ on vascular plants indicate that this compound can interfere with both germination and seedling root elongation. These effects were not species-specific, and plants such as forbs, grasses, shrubs and trees were all effected when exposed to $\mathbf{1}$ at low mM-concentrations. ${ }^{13}$ The inhibitory capacity of compounds 1-13 on the mean root elongation of pre-germinated seeds of Lactuca sativa (Lettuce) was established by placing seedlings on soaked filter papers treated with increasing concentrations of the compounds. The inhibitory effect of the compounds in comparison to treatment with distilled water is presented in Figure 2.

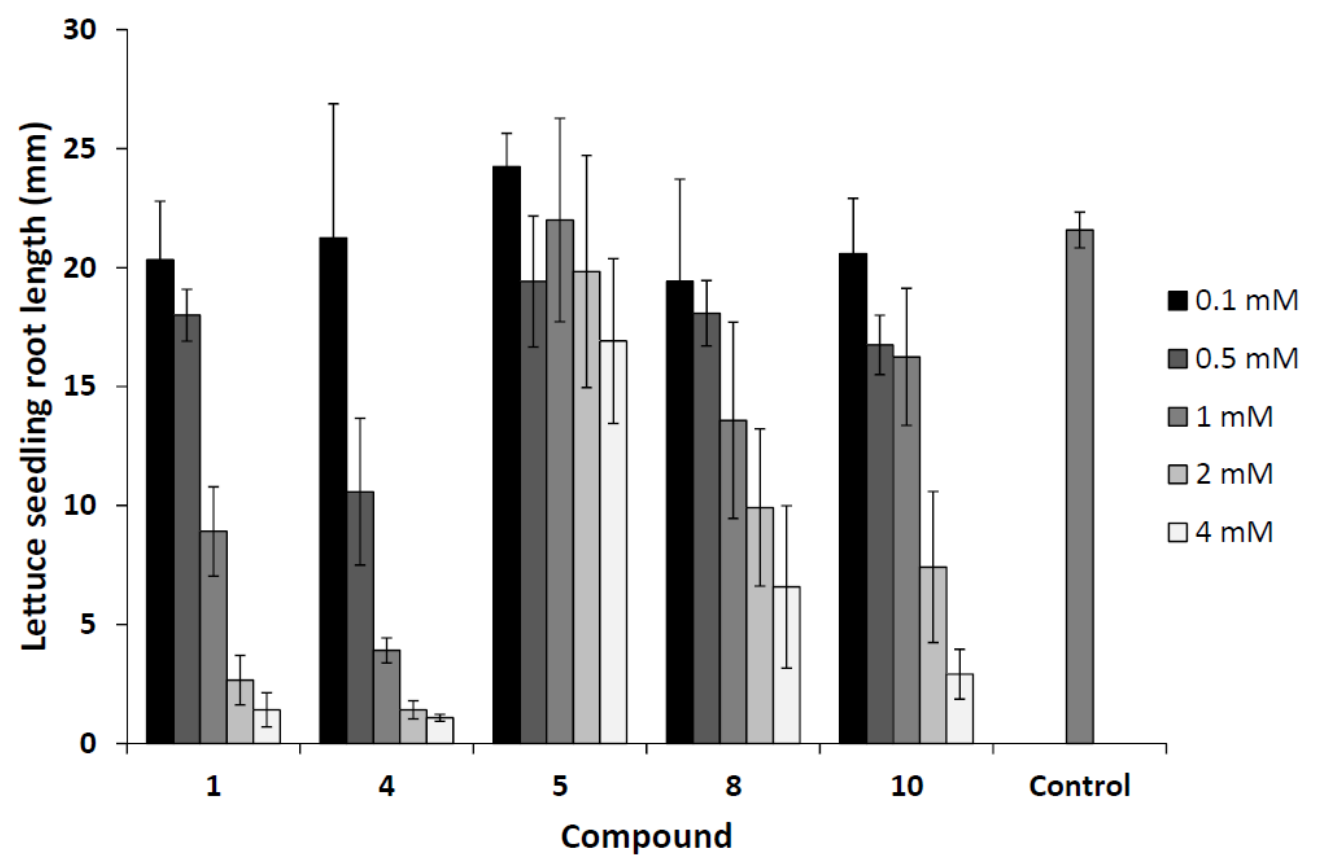

Figure 2. Root length $( \pm \mathrm{SD})$ of $L$. sativa seedlings in response to the inhibitory effect of selected representative dihydrostilbene compounds. Root length estimates are based on a total of 18 seedlings (pre-germinated before incubation) divided into three incubation chambers, and analyzed after three days of incubation. Distilled water was employed as negative control and the compounds were included at concentrations ranging from 0.1 to 4 mM. 
Out of the 13 compounds evaluated, eight displayed an inhibitory effect on the root elongation of $L$. sativa seedlings at $<4 \mathrm{mM}$ concentrations. The $\mathrm{IC}_{50}$ values of the active compounds were determined and are presented in Table 1.

Table 1. Lactuca sativa Seedling Root Elongation Inhibition by Compounds 1-13

\begin{tabular}{lcccc}
\hline compound & $\mathrm{M}_{\mathrm{w}}$ & $\mathrm{CLogP}^{a}$ & $\mathrm{IC}_{50}(\mathrm{mM})^{b}$ & root growth at $4 \mathrm{mM}(\%)^{c}$ \\
\hline $\mathbf{1}$ & & & & \\
$\mathbf{2}$ & 244.29 & 3.35 & 1 & 7.4 \\
$\mathbf{3}$ & 198.26 & 3.92 & 0.5 & 4.4 \\
$\mathbf{4}$ & 212.29 & 4.51 & $>4$ & 92.6 \\
$\mathbf{5}$ & 214.26 & 3.25 & 0.5 & 5.8 \\
$\mathbf{6}$ & 242.31 & 4.60 & $>4$ & 77.9 \\
$\mathbf{7}$ & 214.26 & 3.32 & 0.5 & 10.3 \\
$\mathbf{8}$ & 228.29 & 3.77 & $>4$ & 79.4 \\
$\mathbf{9}$ & 228.29 & 3.77 & 2 & 14.7 \\
$\mathbf{1 0}$ & 242.31 & 4.25 & $>4$ & 73.5 \\
$\mathbf{1 1}$ & 230.26 & 2.59 & 2 & 13.2 \\
$\mathbf{1 2}$ & 230.26 & 2.59 & 2 & 19.1 \\
$\mathbf{1 3}$ & 272.34 & 4.52 & 2 & 42.6 \\
& 272.34 & 4.52 & $>4$ & 79.4
\end{tabular}

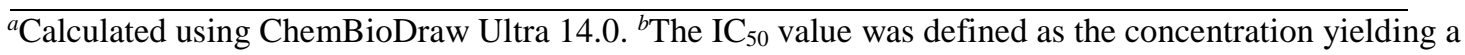
$50 \%$ reduction in root elongation compared to that of distilled water. ${ }^{c}$ In comparison (\%) to the root elongation seen for distilled water.

Compound 1 displayed an $\mathrm{IC}_{50}$ of $1 \mathrm{mM}$ which is in good agreement with previous studies that reported the $\mathrm{IC}_{50}$ at 1-2 $\mathrm{mM} \cdot{ }^{13}$ Compounds $\mathbf{2 ,}, \mathbf{4}$ and $\mathbf{6}$, which are less substituted in comparison to $\mathbf{1}$, were the most potent inhibitors with $\mathrm{IC}_{50}$ values of $0.5 \mathrm{mM}$. Compounds $\mathbf{8}$, 10, 11 and 12 were slightly inferior to 1 whereas compounds 3, 5, 7, 9 and 13 did not display a high enough inhibitory activity to allow for an $\mathrm{IC}_{50}$ determination. Although the latter compounds were not particularly active at $4 \mathrm{mM}$, they still displayed some inhibitory capacity in comparison to distilled water. It is clear that the allelopathic inhibitory effect is not restricted to the natural product $\mathbf{1}$. Indeed several of the synthetic analogues displayed comparable and, in some cases, superior inhibition in the root elongation assay. The structural 
link to activity is not obvious given that both active and inactive compounds are mono-, diand trisubstituted. However, it appeared that hydroxy groups are beneficial for the inhibitory activity. A pair-wise analysis of these analogues with their analogous methoxy counterparts supports this; compounds 2, 4 and $\mathbf{6}$ are all highly active whereas their methoxylated counterparts $\mathbf{3}, \mathbf{5}, \mathbf{7}$, and $\mathbf{9}$ are inactive (compound $\mathbf{8}$, with both a free hydroxy and a methoxy group displayed an $\mathrm{IC}_{50}$ of $2 \mathrm{mM}$ ). This trend was also noticeable for the four trisubstituted analogues, although not as pronounced. Methylation of the hydroxyl groups increases the hydrophobicity of the compounds and lowers the ability to engage in hydrogen bonding interactions, which could provide a link between the free hydroxyl groups and bioactivity. There appears to be no link between the $3^{\prime}, 4^{\prime}$ and 3,5 substitution pattern as compounds 4 and 6 are equally active. The phytotoxicity of 1, $\mathbf{1 0}$ and $\mathbf{1 1}$ against both Amaranthus hypochondriacus and Lemna paucicostata have been investigated by Mata and co-workers. ${ }^{38}$ In their study 1, 10 and $\mathbf{1 1}$ displayed a pronounced phytotoxic effect and caused increased cellular leakage.

Given the observed inhibitory activities of our analogues against root elongation and the recently established inhibitory effect against seed germination ${ }^{13}$ of $\mathbf{1}$, it was decided to evaluate this natural terrestrial scaffold in a marine setting employing diverse species involved in the formation of the biofouling film. ${ }^{39}$ For this purpose, compounds 14-22 were prepared and included in the continued studies to generate additional structural diversity.

To remain within the plant kingdom, the effect on the adhesion and growth of microalgae was initially investigated using the methods described by Trepos et al. ${ }^{29,39}$ employing the commercial antifouling biocide Sea-nine $211^{\mathrm{TM}}$ as a positive control. Sea-Nine $211^{\mathrm{TM}}$ is a herbicide and an inhibitor of PSII electron transport. This compound degrades rapidly in the 
ocean, and is employed in antifouling paint formulations. ${ }^{40,41}$ The ability of the compounds to interfere with surface adhesion and growth (A and $\mathrm{G}$ respectively in Table 2 below) of the microalage Cylindrotheca closterium, Halamphora coffeaeformis, Pleurochrysis roscoffensis, Porphyridium purpureum is presented in Table 2.

Table 2. MIC ${ }^{a}$ (in $\mu \mathrm{g} / \mathrm{mL}$ ) of Batatasin-III (1) and Analogues Against the Adhesion (A) and Growth (G) of Microalgae

\begin{tabular}{lcccccccc}
\hline & \multicolumn{2}{c}{ H. coffeaformis } & \multicolumn{2}{c}{ P. roscoffensis } & \multicolumn{2}{c}{ C. closterium } & \multicolumn{2}{c}{ P. purpureum } \\
Compound & $\mathrm{A}$ & $\mathrm{G}$ & $\mathrm{A}$ & $\mathrm{G}$ & $\mathrm{A}$ & $\mathrm{G}$ & $\mathrm{A}$ & $\mathrm{G}$ \\
\hline $\mathbf{1}$ & & & & & & & & \\
$\mathbf{2}$ & 10 & 10 & 10 & 10 & 10 & 10 & - & 10 \\
$\mathbf{3}$ & 0.01 & 0.01 & 0.01 & 0.01 & 0.01 & 0.1 & 1 & 1 \\
$\mathbf{4}$ & 10 & 1 & 10 & 1 & 10 & 1 & - & 10 \\
$\mathbf{5}$ & 10 & 0.01 & 0.1 & 0.1 & 0.1 & 0.1 & 10 & 10 \\
$\mathbf{6}$ & 0.1 & 0.01 & 0.1 & 0.01 & 10 & 1 & 10 & 10 \\
$\mathbf{7}$ & - & 10 & - & - & - & - & - & - \\
$\mathbf{8}$ & 0.01 & 0.01 & 0.1 & 0.01 & 0.01 & 0.01 & 1 & 0.1 \\
$\mathbf{9}$ & 0.01 & 0.01 & 0.01 & 0.01 & 0.1 & 0.01 & 1 & 1 \\
$\mathbf{1 0}$ & 1 & 0.01 & 1 & 0.01 & 0.1 & 0.01 & 10 & 1 \\
$\mathbf{1 1}$ & 10 & 1 & 1 & 0.1 & 1 & 0.01 & - & 1 \\
$\mathbf{1 2}$ & 0.01 & 0.01 & 1 & 1 & 0.01 & 0.01 & 1 & 0.1 \\
$\mathbf{1 3}$ & 10 & 1 & 10 & 1 & 1 & 1 & - & 10 \\
$\mathbf{1 4}$ & 10 & 10 & 1 & 10 & 1 & 10 & - & - \\
$\mathbf{1 5}$ & 10 & 1 & 10 & 1 & 0.1 & 0.1 & - & 10 \\
$\mathbf{1 6}$ & 0.01 & 1 & 0.01 & 1 & 0.01 & 0.1 & 0.01 & 1 \\
$\mathbf{1 7}$ & 0.01 & 0.01 & 0.01 & 0.01 & 0.01 & 0.01 & 0.1 & 1 \\
$\mathbf{1 8}$ & 1 & 10 & 0.01 & 1 & 0.01 & 0.01 & 0.1 & 0.1 \\
$\mathbf{1 9}$ & - & 10 & - & 10 & - & 10 & - & - \\
$\mathbf{2 0}$ & 0.01 & 0.01 & 0.1 & 0.01 & 0.1 & 0.1 & 1 & 0.1 \\
$\mathbf{2 1}$ & - & 10 & - & 10 & - & 10 & - & - \\
$\mathbf{2 2}$ & 0.01 & 0.01 & 0.1 & 0.1 & 0.01 & 0.01 & 10 & 1 \\
Sea-nine & 0.01 & 1 & 0.01 & 0.1 & 0.1 & 0.01 & 1 & 1 \\
& $<0.01$ & $<0.01$ & $<0.01$ & $<0.01$ & $<0.01$ & $<0.01$ & $<0.01$ & $<0.01$ \\
\hline & & & & & & & & \\
\hline
\end{tabular}

${ }^{a}$ Minimum inhibitory concentration. ${ }^{b}$ Not active at $>10 \mu \mathrm{g} / \mathrm{mL} .{ }^{c}$ Data from Trepos et al. ${ }^{39}$

With the exception of compounds $\mathbf{6}, \mathbf{1 8}$ and 20, all the investigated compounds displayed a high general inhibitory activity against microalgae. The antialgal effect was apparent both towards adhesion and growth. Several of the compounds displayed low MIC-values at sub $\mu \mathrm{g} / \mathrm{mL}$ concentrations. In comparison with other natural antifouling compounds and their 
synthetic analogues evaluated against the same algal species, the current library displays superior antifouling activity towards the microalgae. ${ }^{29,42,43}$ The inhibitory effect on the algal adhesion is particularly noteworthy. The species C. closterium, H. coffeaeformis, $P$. roscoffensis all display similar sensitivity towards the investigated dihydrostilbenes while $P$. purpureum is more resilient. These observations are consistent with other studies identifying P. purpureum as a particularly robust microalgae. ${ }^{39,43}$ Both $C$. closterium and $H$. coffeaeformis are diatoms and it appears that the compounds display a similar high activity towards this class of microalgae. As both $\mathbf{1}$ and $\mathbf{6}$ were highly active in the root elongation inhibition assay, it is interesting to observe that they are relatively poor at the inhibition of microalgae growth and adhesion. It is clear that the link between structure and activity is not the same when going from the terrestrial forb L. sativa to marine microalgae. It could be interpreted that these allelopathic compounds are highly active against both types of plants but potentially via different modes of action. No clear link between the structure of the compounds and their biological effect is seen towards the microalgae. It was unexpected to see such a diverse bioactivity amongst the tetrasubstituted analogues, with compounds $\mathbf{1 6}, \mathbf{1 9}$ and 21 representing some of the most active antialgal compounds. Conversely the structurally related compounds $\mathbf{1 8}$ and $\mathbf{2 0}$ are among the poorer inhibitors. In an attempt to further investigate the antialgal mode of action, after incubation with the compounds for MIC calculation, algal cells were transferred to fresh medium and incubated for five days. The recovered cells displayed normal growth (data not shown) illustrating that dihydrostilbenes appear to act via a reversible biostatic mechanism as opposed to a direct toxic mode of action.

The microfouling of a surface involves contributions from both microalgae and marine bacteria $^{44}$ and can induce a considerable increase in drag as well as biocorrosion. ${ }^{45,46}$ Ten strains of marine bacteria involved in biofouling were tested against the compound library and 
results are presented in Table 3. Only the inhibitory effect on bacterial growth ("G" in the Table 3.) is displayed as none of the compounds exhibited any significant inhibitory effect towards bacterial adhesion at the concentrations employed.

Table 3. MIC ${ }^{a}$ (in $\mu \mathrm{g} / \mathrm{mL}$ ) of Batatasin-III (1) and Analogues Against the Growth of Marine Bacteria $^{b}$

\begin{tabular}{|c|c|c|c|c|c|c|c|c|c|c|}
\hline Compound $^{c}$ & V.a. & V.c. & V.h. & V.n. & V.p. & H.a. & R.l. & S.p. & P.i. & P.e. \\
\hline 1 & $-d$ & 1 & - & - & - & - & - & 10 & 1 & 10 \\
\hline 2 & 0.1 & 0.01 & 0.1 & 0.01 & - & - & - & 0.01 & - & - \\
\hline 3 & 0.01 & - & 1 & - & 0.01 & - & 10 & - & - & - \\
\hline 4 & 0.01 & - & 0.1 & - & 1 & 0.01 & 0.1 & 0.1 & - & - \\
\hline 5 & - & - & - & - & - & 0.01 & - & 0.01 & - & - \\
\hline 6 & 0.1 & - & 1 & - & 10 & 10 & 10 & - & - & - \\
\hline 8 & - & - & - & - & - & 10 & - & - & - & - \\
\hline 9 & 10 & - & - & - & - & 0.01 & 10 & 0.1 & - & 10 \\
\hline 11 & 1 & - & 1 & - & - & - & 10 & 0.01 & - & 0.01 \\
\hline 13 & - & - & - & - & - & - & - & 1 & - & - \\
\hline 14 & - & - & - & - & 1 & 0.01 & - & 0.1 & - & - \\
\hline 15 & 0.01 & - & 0.01 & - & 0.01 & 1 & - & - & - & - \\
\hline 17 & 10 & - & 10 & - & 0.01 & - & - & - & - & - \\
\hline 18 & 10 & 0.1 & 10 & 0.01 & - & 0.01 & - & 0.01 & - & - \\
\hline 21 & - & - & - & - & 0.1 & - & - & - & 0.1 & - \\
\hline Sea-nine ${ }^{\mathrm{TM}}, e$ & $<0.01$ & $<0.01$ & 1 & 1 & 0.01 & 0.1 & 1 & 1 & 1 & 0.1 \\
\hline
\end{tabular}
harveyi, Vibrio natriegens, Vibrio proteolyticus, Halomonas aquamarina, Roseobacter litoralis, Shewanella putrefaciens, Polaribacter irgensii and Pseudoalteromonas elyakovii. ${ }^{c}$ Compound 7, 10, 12, 16, 19, 20 and 22 were all inactive against the growth of bacteria up to $10 \mu \mathrm{g} / \mathrm{mL} .{ }^{d}$ Not active at $>10 \mu \mathrm{g} / \mathrm{mL} .{ }^{e}$ From Trepos et al. ${ }^{39}$

The effects of 1-22 on the marine bacteria were less prominent than was observed against microalgae. Inhibition of bacterial growth was observed for two thirds of the compounds but these effects were species-specific. For example compounds 2, 4, 6, 9, 11 and 18 were active against of half of the included bacterial strains. Vibrio carchariae, Vibrio natriegens, and Polaribacter irgensii were sensitive to three out of the 22 compounds and represent bacteria less sensitive to this class of compounds. No direct link between the structure of the 
compounds and their antibacterial properties was apparent and the results suggest that the dihydrostilbenes are not general inhibitors of the adhesion or growth of marine bacteria.

Although microfouling is an important step in the development of biofouling communities, the majority of unwanted weight gain and increased drag on marine structures results from the accumulation of macrofoulers. The metamorphosis inhibition and settlement of barnacle cyprids was used to evaluate the ability of the dihydrostilbene scaffold to limit the settlement of a common macrofouling taxon. Balanus improvisus has been employed in antifouling studies of numerous natural products and represent a relevant crustacean model species for temperate and cold waters..$^{29,42,43}$ The inhibitory effect of the compounds on cyprid settlement was initially assessed at $5 \mu \mathrm{g} / \mathrm{mL}$ (Figure 3 ). The $\mathrm{IC}_{50}$ of the active compounds were subsequently determined via dose-response studies as presented in Table 4.

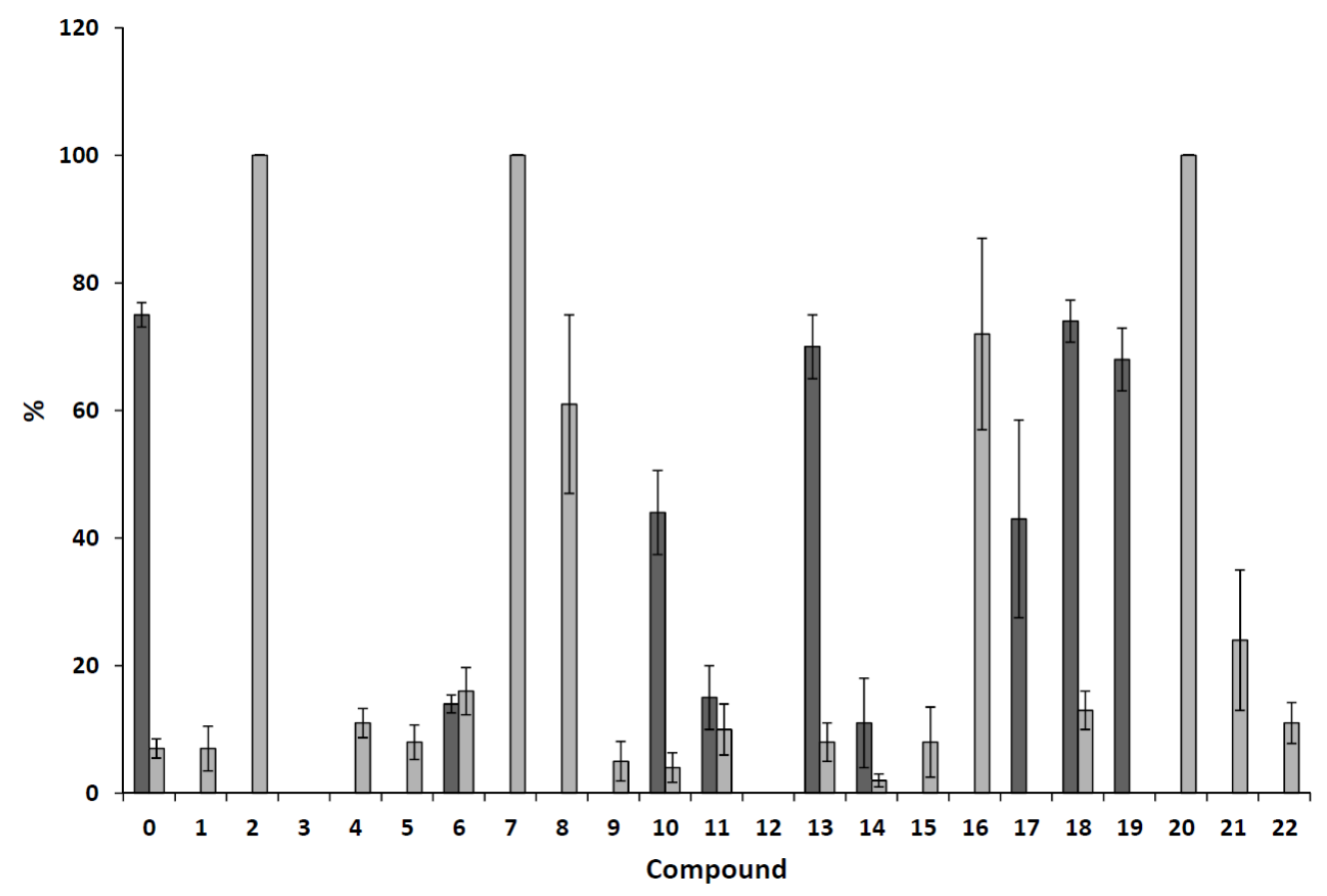

Figure 3. Effects of 1-22 at $5 \mu \mathrm{g} / \mathrm{mL}$ on the settlement of B. improvisus cyprid larvae presented as percentages of settled (dark gray columns) and dead cyprids (light gray columns) and given as means \pm standard error ( $n=$ 4). Remaining larvae were free swimming. DMSO $(0.1 \%, \mathrm{v} / \mathrm{v})$ in filtered seawater was used as the negative control “0”. 
Table 4. Potency and Toxicity of $\mathbf{1}$ and Analogues Against the Barnacle B. improvisus.

\begin{tabular}{lcccc}
\hline compound & $\mathrm{M}_{\mathrm{w}}$ & $\mathrm{CLogP}^{a}$ & $\mathrm{IC}_{50}(\mu \mathrm{g} / \mathrm{mL})$ & ${\text { toxicity }(\%)^{b}}^{b}$ \\
$\mathbf{1}$ & 244.29 & 3.35 & 1.0 & 7.0 \\
$\mathbf{2}$ & 198.26 & 3.92 & 0.5 & 100 \\
$\mathbf{3}$ & 212.29 & 4.51 & 0.75 & 0.0 \\
$\mathbf{4}$ & 214.26 & 3.25 & 1.0 & 11.1 \\
$\mathbf{5}$ & 242.31 & 4.60 & 1.0 & 7.7 \\
$\mathbf{6}$ & 214.26 & 3.32 & 1.0 & 16.0 \\
$\mathbf{7}$ & 228.29 & 3.77 & 1.0 & 100 \\
$\mathbf{8}$ & 228.29 & 3.77 & 0.75 & 60.8 \\
$\mathbf{9}$ & 242.31 & 4.25 & 0.75 & 5.3 \\
$\mathbf{1 0}$ & 230.26 & 2.59 & 5.0 & 3.6 \\
$\mathbf{1 1}$ & 230.26 & 2.59 & 1.5 & 10.0 \\
$\mathbf{1 2}$ & 272.34 & 4.52 & 0.75 & 0.0 \\
$\mathbf{1 3}$ & 272.34 & 4.52 & $>5$ & 8.0 \\
$\mathbf{1 4}$ & 258.31 & 3.94 & 1.0 & 2.0 \\
$\mathbf{1 5}$ & 244.29 & 3.17 & 1.5 & 8.4 \\
$\mathbf{1 6}$ & 274.31 & 3.20 & 2.5 & 71.9 \\
$\mathbf{1 7}$ & 246.26 & 1.99 & 5.0 & 0.0 \\
$\mathbf{1 8}$ & 260.29 & 2.44 & $>5$ & 12.9 \\
$\mathbf{1 9}$ & 260.29 & 2.44 & $>5$ & 0.0 \\
$\mathbf{2 0}$ & 288.34 & 3.78 & 0.25 & 100 \\
$\mathbf{2 1}$ & 288.34 & 3.78 & 1.5 & 24.3 \\
$\mathbf{2 2}$ & 302.36 & 4.25 & 1.0 & 10.9 \\
Sea-nine & 282.20 & 4.90 & 0.25 & n.d. \\
& & & & \\
\hline & & & & \\
\hline
\end{tabular}

${ }^{a}$ Calculated using ChemBioDraw Ultra 14.0. ${ }^{b}$ Reported at $5 \mu \mathrm{g} / \mathrm{mL}$. Toxicity for the negative control DMSO $(0.1 \%, \mathrm{v} / \mathrm{v})$ in filtered seawater was $7.5 \% .{ }^{c}$ Not determined.

As illustrated in Figure 6 there is a substantial spread in the potency against B. improvisus of the analyzed compounds when evaluated at $5 \mu \mathrm{g} / \mathrm{mL}$. Compounds 13,18 and 19 exhibited no effect on the settling behavior of the B. improvisus cyprids at $5 \mu \mathrm{g} / \mathrm{mL}$, whilst several other compounds completely inhibited settlement under the same conditions. At $5 \mu \mathrm{g} / \mathrm{mL}$, compounds 2, 7 and 20 killed all cyprids. In contrast, compounds 3, 9 and 12 inhibited settlement of the cyprids but did not kill them - indicating a non-toxic mode of action. This finding implies that within a compound library, different mode of actions may be operating. 
Dose-response analysis of the active compounds revealed $\mathrm{IC}_{50}$ values in the low $\mu \mathrm{g} / \mathrm{mL}$ concentration range with a number of compounds displaying settlement inhibition at concentrations $<1 \mu \mathrm{g} / \mathrm{mL}$. These inhibitory activities are higher than those reported for the large majority of previously investigated antifouling natural products ${ }^{26,27,47}$ and are comparable to commercial antifouling products including Sea-nine ${ }^{\mathrm{TM}}$. The most active compounds $2,3,8,9,12$ and 20 perform similarly $\left(\mathrm{IC}_{50}=0.9-3.5 \mu \mathrm{M}\right)$ to the highly active natural drimane sesquiterpene polygodial $\left(\mathrm{IC}_{50}=1.1 \mu \mathrm{M}\right),{ }^{43}$ the 2,5 -diketopiperazine barettin $\left(\mathrm{IC}_{50}=0.9 \mu \mathrm{M}\right),{ }^{48}$ bastadin-9 $\left(\mathrm{IC}_{50}=1.0 \mu \mathrm{M}\right)^{49}$ and synoxazolidinone $\mathrm{C}\left(\mathrm{IC}_{50}=2 \mu \mathrm{M}\right) .{ }^{29}$ The compounds also share similar structural features and antifouling activities with the natural antifouling phenyl ethers recently reported by Wang and co-workers. ${ }^{50}$

The high inhibitory effect on barnacle cyprid settlement illustrates that the dihydrostilbenes also exhibit potent biological effects in higher organisms. An influential physicochemical factor for the settlement inhibition of the analyzed compounds appears to be the hydrophobicity and hydrogen-bond forming capacity. With the exception of compound $\mathbf{1 3}$, all other compounds $(\mathbf{1 1}, \mathbf{1 7}, \mathbf{1 8}$ and 19) displaying low or no inhibitory activity are hydrophilic, with $\mathrm{C} \log \mathrm{P}$ values ranging between 1.99 and 2.59. These poorly active compounds are substituted with a minimum of three hydroxy groups yielding, not only improved water solubility, but also an increased ability, to engage in hydrogen bonding with biological targets. For inhibition of barnacle cyprid settlement, these properties reduce the activity of the dihydrostilbene scaffold, which is in direct contradiction to the relationship seen for the $L$. sativa root elongation inhibition. The observation that a high number of free hydroxyl groups may lower the antifouling activity against balanides is consistent with the findings reported by Wang and co-workers. ${ }^{50}$ 
Apart from the clear connection between increased polarity and hydrogen bond capacity and a lowered inhibitory effect towards cyprid metamorphosis, there are few defined relationships between structure and activity. However, the non-toxic analogues 3, 9 and $\mathbf{1 2}$ contain no free hydroxyl groups and subsequently have lower water solubility. In fact, none of the more hydrophobic analogues with $C \log P$ values between 4.25 and $4.60(\mathbf{3}, \mathbf{5}, \mathbf{9}, \mathbf{1 2}, 13$ and 22) display any toxicity at $5 \mu \mathrm{g} / \mathrm{mL}$. Of further interest, the toxic analogues (compounds $\mathbf{2}, \mathbf{7}, \mathbf{8}$, 16, 20, and 21) all display a similar overall polarity, with ClogP values between 3.20 and 3.78. These results indicate that the investigated scaffold has a broad inhibitory activity, with the more hydrophobic compounds inhibiting cyprid settlement whilst not displaying generally toxic effects as graphically shown in Figure 4. These observations suggest that the antifouling structure-activity-relationship of the dihydrostilbenes towards barnacles is dictated by overall polarity and not a defined hydroxy and methoxy substitution pattern.

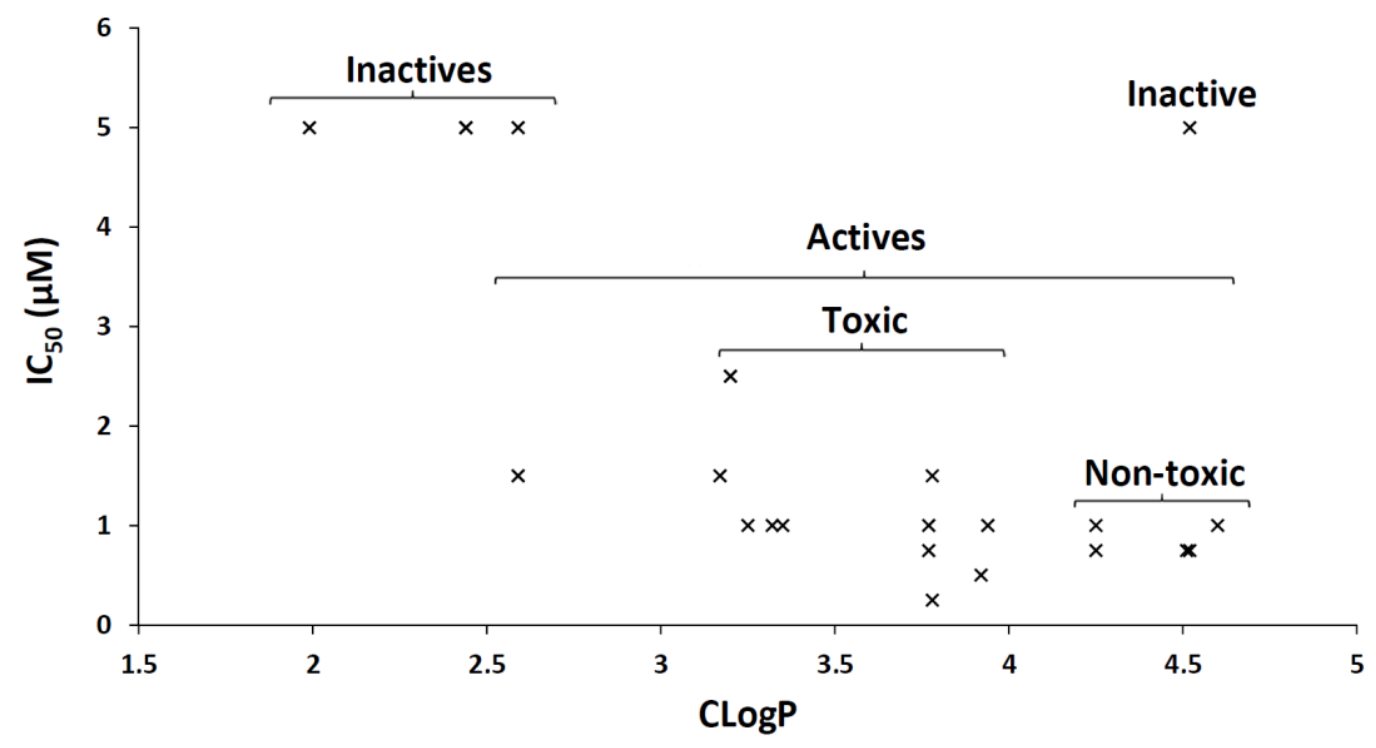

Figure 4. Graphical representation of the correlation between hydrophobicity (CLogP), inhibition of cyprid settlement $\left(\mathrm{IC}_{50}\right)$ and cyprid toxicity for the studied compounds. Inactive compounds with $\mathrm{IC}_{50^{-}}$values $>5 \mu \mathrm{g} / \mathrm{mL}$ have all been given an inhibitory value of " 5 ". 
To gain additional insight into the spectrum of antifouling activity of the dihydrostilbene scaffold, selected compounds were also evaluated as inhibitors of the settlement and metamorphosis of larvae of the ascidian Ciona savignyi (Ascidiacea). Ascidians settle rapidly on marine substrata and represent a challenging macrofouling species to manage. ${ }^{51}$ Compounds displaying a high inhibitory activity in the barnacle assay were selected for evaluation against $C$. savignyi. Toxic compounds, such as compounds $\mathbf{7}$ and $\mathbf{2 0}$, and non-toxic analogues such as $\mathbf{5 , 9}$ and $\mathbf{2 2}$ were included in addition to $\mathbf{1}$. The compounds were evaluated for their ability to interfere with $C$. savignyi larval metamorphosis and settlement according to the methodology developed by Cahill and coworkers. ${ }^{51,52}$ The dose-response behavior and inhibitory constants are presented in Figure 5 and Table 5.

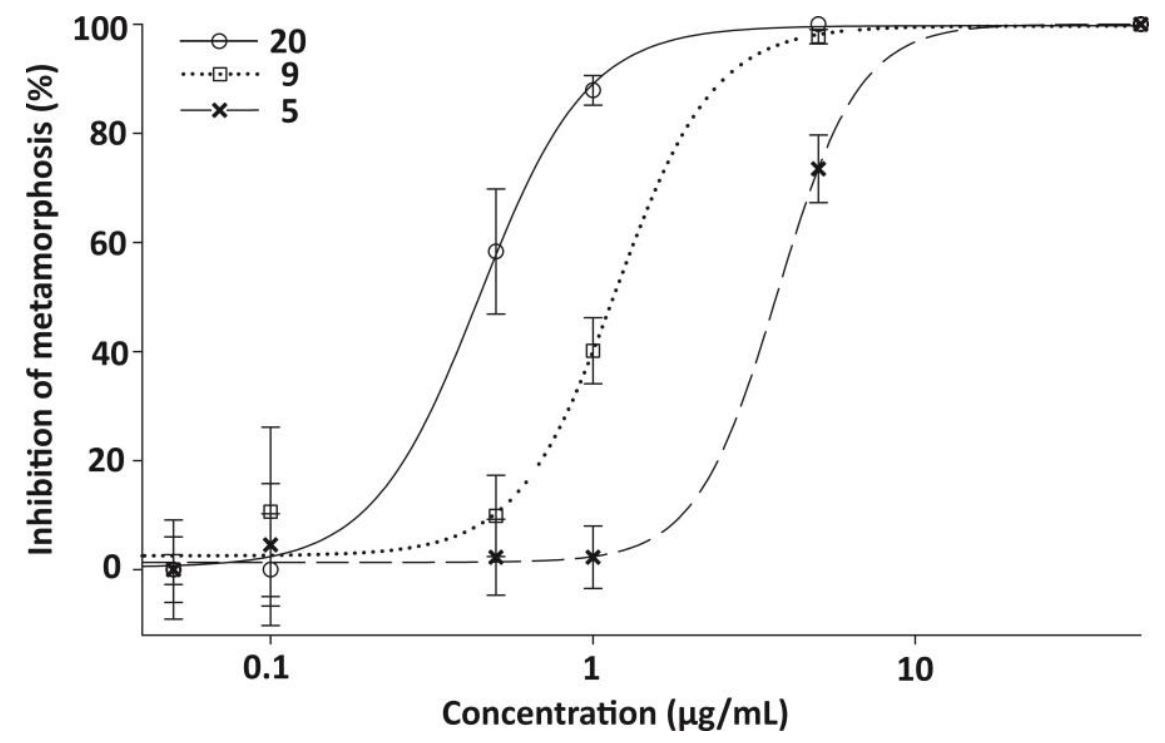

Figure 5. Metamorphosis inhibition of $C$ savignyi larvae exposed to 5, 9 and 20. Inhibition of metamorphosis is relative to corresponding blank controls and values are means $(n=3) \pm$ standard error. 
Table 5. Potency of Selected Compounds Against the Ascidian C. savignyi

\begin{tabular}{lcc}
\hline compound & $\mathrm{IC}_{50}(\mu \mathrm{g} / \mathrm{mL})$ & $\mathrm{IC}_{99}(\mu \mathrm{g} / \mathrm{mL})$ \\
\hline $\mathbf{1}$ & 1.9 & 5.5 \\
$\mathbf{5}$ & 3 & 21.1 \\
$\mathbf{7}$ & 1.1 & 2.6 \\
$\mathbf{9}$ & 1.1 & 7.2 \\
$\mathbf{2 0}$ & 0.4 & 3.5 \\
$\mathbf{2 2}$ & 4.3 & 44.4 \\
Sea-nine & & n.d. ${ }^{b}$ \\
& $0.2^{a}$ & \\
\hline${ }^{a}$ Data taken from Ref. ${ }^{53}$ against Ciona intestinalis. $^{b}$ Not determined.
\end{tabular}

All six of the evaluated compounds inhibited C. savignyi larval metamorphosis at low concentrations, similar to those recorded against $B$. improvisus. Compound $\mathbf{2 0}$ was the most active analogue, displaying an $\mathrm{IC}_{50}$ of $0.4 \mu \mathrm{g} / \mathrm{mL}$. This inhibitory potency correlates well with the data from the barnacle assay performed in the current study, and is comparable to that recently reported by Moodie et al. for synthetic analogues of polygodial. ${ }^{43}$ Of particular interest, 9 exerted its inhibitory activity via a non-toxic mode of action, with active and swimming larvae still present after five days of incubation but no successfully settled or metamorphosed larvae. The remaining compounds killed the $C$. savignyi larvae outright, with no active or swimming larvae present after 5 days. The correlation between a high hydrophobicity and a non-toxic mode of action is not as defined as that seen for B. improvisus due to the toxicity of compounds $\mathbf{5}$ and $\mathbf{2 2}$. However, the overall antifouling activity of the dihydrostilbenes against the two higher marine organisms investigated is pronounced and similar.

Toxicity against other non-target higher marine organisms has been reported for $\mathbf{1}$. The potential toxic effect on the aquatic fauna by the E. nigrum, was evaluated by Brännäs et al. using $1 .^{53}$ The toxicity of $\mathbf{1}$ against brown trout (Salmo trutta) alevins and juvenile water fleas 
(Daphnia magna) was established. It was shown that $\mathbf{1}$ is toxic towards freshly hatched $S$. trutta alevins and juvenile D. magna at $10 \mu \mathrm{g} / \mathrm{mL}$ concentrations. The toxic effect correlated with $\mathrm{pH}$ and increased with water acidity. ${ }^{53}$ No analogues of $\mathbf{1}$ were investigated in their study aside from phenol.

Terrestrial Versus Marine Allelopathy. Allelopathy is successfully used to control the growth and spread of competitive plant species both on land and in the ocean. In forestry it has been shown that natural $\mathbf{1}$ can impact the structure of entire plant communities., ${ }^{2,3}$ The antagonistic relationship between phytoplankton and rooted aquatic plants has been investigated $^{54}$ and several other studies have described the allelopathic effect of marine natural products on marine algal communities. ${ }^{28,55,56}$ Several of these characterized marine allelochemicals are of a phenolic nature, displaying structural similarities with the currently studied terrestrial compounds. ${ }^{56}$ As such, it is clear that the allelopathic phenomenon is ongoing on land and at sea but it is nevertheless unclear if powerful terrestrial allelopathic compound also will effectively target marine organisms to the same extent. Marine algae share some similarities with higher plants, yet in a simpler and less differentiated format. Macrofouling invertebrates share very few features with higher plants, making it more difficult to predict how they will interact with terrestrial allelochemicals.

\section{CONCLUSIONS}

The current study represents the first comprehensive evaluation of a terrestrial allelopathic natural products scaffold in a marine setting with the goal of discovering and developing new green methods to combat marine biofouling. Despite the significant biological uncertainties, the current study clearly demonstrates that the prepared dihydrostilbenes are allelopathic against $L$. sativa and also active against marine algae and two taxa of marine invertebrates. 
The inhibitory effect towards marine microalgae is in fact more pronounced than against $L$. sativa with many of the compounds displaying inhibitory properties at low $\mathrm{ng} / \mathrm{mL}$ concentration via a non-toxic mechanism against both algal adhesion and growth. The observation that these compounds also target the macrofouling invertebrates by both toxic and non-toxic pathways is even more profound, motivating further research into these naturally occurring compounds. Although the exact mechanism of action is unknown, there are clearly relevant molecular targets for dihydrostilbenes that open up new avenues for environmentally friendly strategies to combat unwanted marine growth.

\section{EXPERIMENTAL SECTION}

General Experimental Procedures. NMR spectra were acquired on a Varian $7000 \mathrm{e} 400$ MHz spectrometer. HRMS was recorded on an LTQ Orbitrap XL Hybrid Fourier Transform mass spectrometer from Thermo Scientific. Solvents and reagents were obtained from commercial suppliers and used without further purification. Air-sensitive reactions were carried out under an argon atmosphere. Thin-layer chromatography was carried out on aluminum-backed plates coated with silica gel and visualized under UV light at $254 \mathrm{~nm}$ and ethanolic vanillin dip. Chromatography was carried out on silica gel employing mixtures of petroleum ether and ethyl acetate as eluents. Batatasin-III (1) was purchased (>99 \% purity determined by HPLC) from Paragon Biochemical LLC (Salt Lake City, United States of America). Wittig salts were prepared according to the protocols of Chalal et al. ${ }^{57} 3$ Benzyloxy-5-methoxybenzyl bromide was synthesized by the method of Nawrat et al. ${ }^{58}$ Diethyl 3,5-dibenzyloxybenzylphosphonate was prepared according to the protocol of Sun et al. ${ }^{59}$ 
Marine Organisms. Four pure, but non-axenic, marine microalgae (obtained from Algobank, Caen, France) and ten marine bacterial strains were used in the current study (Table 6). The strains were selected to represent fouling species encountered in both estuarine and marine environments. ${ }^{60,61}$ The bacteria were grown at $26{ }^{\circ} \mathrm{C}$ in a marine medium, composed of $0.5 \%$ peptone (neutralized bacteriological peptone, Oxoid Ltd.) in filtered (11 $\mu \mathrm{m})$ natural seawater. Microalgae were grown at $22{ }^{\circ} \mathrm{C}$ in $\mathrm{F} / 2$ medium prior to use.

Table 6. Biofouling Microorganisms Included in the Present Study

\begin{tabular}{lcc}
\hline species & abbreviation & code \\
\hline & & \\
Marine bacteria & & $\mathrm{ATCC}^{a}$ \\
Halomonas aquamarina & H.a. & 14400 \\
Polaribacter irgensii & $P . i$. & 700398 \\
Pseudoalteromonas elyakovii & $P . e$. & 700159 \\
Roseobacter litoralis & R.l. & 49566 \\
Shewanella putrefaciens & S.p. & 8071 \\
Vibrio aestuarianus & V.a. & 35048 \\
Vibrio carchariae & V.c. & 35084 \\
Vibrio harveyi & V.h. & 700106 \\
Vibrio natriegens & V.n. & 14058 \\
Vibrio proteolyticus & V.p. & 53559 \\
& & \\
Microalgae & & Algobank code \\
Cylindrotheca closterium & & AC 170 \\
Halamphora coffeaeformis & & AC 713 \\
Pleurochrysis roscoffensis & & AC 32 \\
Porphyridium purpureum & & \\
& & \\
american tissue culture code & &
\end{tabular}

Cyprids of B. improvisus were reared at the Lovén Centre for Marine Infrastructure Tjärnö, University of Gothenburg, Sweden and the settlement inhibition was investigated using methods initially described by Berntsson. ${ }^{29,62}$ Newly moulted cyprids were collected and used for the settlement assays. Adult C. savignyi were collected and maintained at the Cawthron Institute, New Zealand as previously described. ${ }^{43}$ Eggs and sperm were harvested from three gravid individuals and transferred to separate $50 \mathrm{~mL}$ glass Petri dishes (Ø $90 \mathrm{~mm})$ 
containing filtered $(3 \mu \mathrm{m})$ and UV-sterilized seawater. The dishes containing eggs received eight drops of sperm suspension from each of the two other individuals. The fertilized eggs were incubated for $1 \mathrm{~h}$ at $18{ }^{\circ} \mathrm{C}$ and strained through a $20-\mu \mathrm{m}$ sieve, rinsed three times with $25 \mathrm{~mL}$ reconstituted seawater (RSW; $33 \pm 0.5$ psu; Red Sea Salt, Red Sea Aquatics, Cheddar, UK). The strained eggs were transferred to a glass Petri dish containing $25 \mathrm{~mL} \mathrm{RSW}$, and incubated for $18 \mathrm{~h}$ at $18{ }^{\circ} \mathrm{C}$ to hatch. Hatched larvae were transferred to conical flasks and diluted with RSW to yield 10 larvae/mL immediately prior to being employed in the inhibition assay.

Lactuca sativa Seedling Roots Assay. The inhibition of L. sativa (lettuce) seedlings through mean root elongation studies of pre-germinated seeds was determined according to González et al. ${ }^{13}$ The compounds were dissolved in $\mathrm{MeOH}$ and added to five filter papers discs $(\varnothing 50 \mathrm{~mm})$ placed in Petri dishes to yield concentrations of 0 (control), 0.1, 0.5, 1.0, 2.0 and $4.0 \mathrm{mM}$. The $\mathrm{MeOH}$ was allowed to evaporate at room temperature before the bioassays were initiated and $1 \mathrm{~mL}$ of distilled water was added to moisten the filter paper before placing pre-germinated seedlings on the soaked filter papers. Three Petri dishes were employed for each compound concentration and six seedlings were placed in each dish. The root length $(\mathrm{mm})$ was measured after three days of growth, after which the average root length per dish, followed by the average root length across all three dishes was calculated to yield an estimate of root length per compound concentration. Finally the inhibitory concentration yielding a $50 \%$ reduction in root length, compared to the control was calculated and reported as the $\mathrm{IC}_{50}$.

Antialgal Assays. Microplates containing the compounds in ranging concentrations were prepared from $\mathrm{MeOH}$ stock solutions as described by Trepos et al. ${ }^{29}$ Microalgal stock solutions were prepared for each strain via chlorophyll analysis according to Chambers et al. ${ }^{60}$ Aliquots $(100 \mu \mathrm{L})$ of the algal stock solutions $(0.1 \mathrm{mg}$ chlorophyll $\mathrm{a} / \mathrm{mL})$ were transferred to 
the pre-treated microplate wells and the plates were grown at $20{ }^{\circ} \mathrm{C}$ for 5 days under constant light exposure $\left(140 \mu \mathrm{mol} \mathrm{m} \mathrm{m}^{-2} \mathrm{~s}^{-1}\right)$. Microalgal growth was assessed by analysis of liberated chlorophyll-a following centrifugation and addition of $\mathrm{MeOH}(100 \%)$. The released chlorophyll-a was quantified using a fluorometric method described by Chambers et al. ${ }^{60}$ The lowest concentration yielding a decrease in chlorophyll-a content was defined as the minimum inhibitory concentration (MIC) for algal growth. Microalgal adhesion was determined in a similar manner in which the non-attached algal cells were gently removed prior to addition of $100 \mu \mathrm{L}$ of $100 \%$ methanol to release chlorophyll-a from the remaining algal biofilms. The MIC for adhesion was defined as the lowest compound concentration inducing a reduction in optical density. When inhibition was observed, a toxicity test was performed by transferring the content of the wells into a flask of fresh medium. The growth of the initially inhibited strains was measured after 5 days of additional incubation and the mode of action of classified as biostatic if an increase in chlorophyll-a content was observed. ${ }^{43}$ The commercial antifouling agent Sea-nine ${ }^{\mathrm{TM}}$ served as a positive control.

Antibacterial Assays. Adhesion and growth of the bacterial strains was assessed according to Thabard et al. ${ }^{63}$ Briefly, aliquots $(100 \mu \mathrm{L})$ of bacterial suspension $\left(2 \times 10^{8}\right.$ colony forming units $/ \mathrm{mL}$ ) were aseptically added to the pre-treated microplate wells and the plates were incubated at $26{ }^{\circ} \mathrm{C}$ for $48 \mathrm{~h}$. Bacterial growth was investigated spectroscopically and the lowest concentration yielding a decrease in OD at $630 \mathrm{~nm}$ was defined as the MIC for bacterial growth. The adhesion of bacteria was determined by staining the residual attached bacterial biofilms with $0.3 \%$ aqueous crystal violet (v/v) after emptying and rinsing the incubated wells with $100 \mu \mathrm{L}$ of FSW after $48 \mathrm{~h}$ of incubation. The stained bacterial biofilms were visualized at $595 \mathrm{~nm}$ according to Sonal and Bholse. ${ }^{64}$ The MIC for adhesion was defined as the lowest concentration inducing a reduction in OD at $595 \mathrm{~nm}$. Toxicity 
experiments were performed as described for the microalgae. The commercial antifouling agent Sea-nine ${ }^{\mathrm{TM}}$ served as a positive control.

Balanide Settlement Inhibition. The compounds were prepared as stock solutions in DMSO and serially diluted to generate final concentrations ranging from 0.1 to $10 \mu \mathrm{g} / \mathrm{mL}$ in untreated polystyrene Petri dishes, containing $10 \mathrm{~mL}$ filtered $(0.2 \mu \mathrm{m})$ seawater. Newly molted cyprids (18 - 22) were added to each test dish, which were subsequently incubated at ambient temperature $\left(20-25^{\circ} \mathrm{C}\right)$ for 5 days. The extent of cyprid metamorphosis was assessed under a dissecting microscope and juvenile settled barnacles, as well as live and dead cyprids, were counted. The concentration preventing 50\% of the cyprid settlement on the Petri dish surface was defined as the $\mathrm{IC}_{50}$ values. An initial screen was performed at $5 \mu \mathrm{g} / \mathrm{mL}$ for all the compounds and a full $\mathrm{IC}_{50}$ determination was only performed on those compounds displaying $>50 \%$ inhibition at that concentration. Each test concentration of the compounds was replicated four times $(n=4)$, and dishes with $10 \mu \mathrm{L}$ of DMSO served as negative controls. The commercial antifouling agent Sea-nine ${ }^{\mathrm{TM}}$ served as a positive control.

Ascidian Antifouling Bioassay. The ascidian bioassay was run in twelve-well tissue culture plates (Corning® Costar®, Corning Inc., Corning, NY; Ø $23 \mathrm{~mm}$ ), containing $7.1 \mathrm{~mL}$ aliquots of a larval suspension (containing 10 larvae/mL) according to Cahill et al. ${ }^{52}$ The compounds were prepared as $20 \%$ (v/v) ethanol stock solutions and were added to wells to yield final concentrations ranging from 0.001 to $20 \mu \mathrm{g} / \mathrm{mL}$. The blank control contained carrier solvent only. Three replicates were performed for each treatment concentration and control $(n=3)$. The plates were incubated at $18 \pm 1^{\circ} \mathrm{C}, 12: 12 \mathrm{~h}$ subdued light to dark for 5 days, after which the number of larvae that had settled and completed metamorphosis were counted. Dose-response curves were plotted using four parameter logistic curve fitting on SigmaPlot 11.0. ${ }^{65}$ The corresponding compound concentrations that reduced the number of 
larvae completing metamorphosis and settlement by $50 \%\left(\mathrm{IC}_{50}\right)$ were calculated relative to blank controls.

Synthesis. All the prepared dihydrostilbenes are known compounds and have previously been described in the literature. General synthetic procedures are described below. All the prepared compounds matched the previously reported spectroscopic data. The complete characterization of compounds $\mathbf{2 - 2 2}$ can be found in the Supporting Information.

General Procedure for Wittig Reaction. $\mathrm{NaH}$ (95\%, 1.05 equiv.) was added to a stirred solution of Wittig salt (1.0 equiv.) in $\operatorname{THF}(0.1 \mathrm{M})$ at $0{ }^{\circ} \mathrm{C}$. A solution of aldehyde (1.0 equiv.) in THF (0.1 M) was added dropwise and the reaction allowed to warm to ambient temperature. After $14 \mathrm{~h}$ the reaction was quenched with $\mathrm{H}_{2} \mathrm{O}$ and extracted with ethyl acetate $(\times 2)$. The combined organic extracts were washed with $\mathrm{H}_{2} \mathrm{O}$, brine and dried over $\mathrm{Na}_{2} \mathrm{SO}_{4}$. The solvent was removed in vacuo, and the resulting residue purified by column chromatography (petroleum ether-ethyl acetate) to afford the product as an inconsequential mixture of $E$ and $Z$ isomers, as determined by ${ }^{1} \mathrm{H}$ NMR analysis.

General Procedure for Hydrogenation. The reaction vessel was evacuated and flushed with $\mathrm{N}_{2}$ prior to addition of $\mathrm{Pd} / \mathrm{C}(10 \%)$ (33 mg/mmol of substrate). Ethyl acetate was added to the flask followed by a solution of substrate (1.0 equiv., mixture of $E$ and $Z$ isomers) in ethyl acetate (final concentration $\sim 0.1 \mathrm{M}$ ). The reaction flask was evacuated and backfilled with $\mathrm{N}_{2}(\times 2)$ prior to evacuation and introduction of a $\mathrm{H}_{2}$ balloon $(\times 2)$. After stirring overnight, the vessel was flushed with $\mathrm{N}_{2}$ and the reaction mixture filtered through a bed of Celite. The Celite was washed with ethyl acetate and the solvent removed under reduced 
pressure. The resulting residue was purified by column chromatography (petroleum etherethyl acetate) to afford the desired bibenzyl compound.

General Procedure for Demethylation. $\mathrm{HBr}\left(48\right.$ wt. \% in $\left.\mathrm{H}_{2} \mathrm{O}\right)$ was added to a solution of substrate in glacial acetic acid $(\mathrm{HBr}-\mathrm{AcOH} 1: 1 \mathrm{v} / \mathrm{v}$, final concentration $0.15 \mathrm{M})$. The reaction mixture was refluxed for $3 \mathrm{~h}$ and cooled to room temperature. After the addition of water, the reaction mixture was extracted with diethyl ether $(\times 3)$ and the combined organic extracts washed with $\mathrm{H}_{2} \mathrm{O}$, brine and dried over $\mathrm{Na}_{2} \mathrm{SO}_{4}$. After the removal of solvent, the product was purified by column chromatography.

General Procedure for Horner-Wadsworth-Emmons Reaction. ${ }^{59} \mathrm{NaH}$ (95\%, 6.0 equiv.) was added to a cooled $\left(0{ }^{\circ} \mathrm{C}\right)$ solution of phosphonate (1.0 equiv.) in THF under an inert atmosphere. The reaction was allowed to warm to ambient temperature and stirred for 30 min before addition of aldehyde (1.2 equiv.) in THF. The reaction was then refluxed at $75{ }^{\circ} \mathrm{C}$ for 1 h. After cooling to room temperature the reaction was quenched by the addition of $1 \mathrm{M} \mathrm{HCl}$ and the resulting mixture extracted into $\mathrm{CHCl}_{3}(\times 3)$. The combined organic layers were washed with water, brine and dried over $\mathrm{Na}_{2} \mathrm{SO}_{4}$. The residue was concentrated and purified by column chromatography (petroleum ether-ethyl acetate) to afford the desired alkene.

1-Methoxy-3-phenethylbenzene (3) ${ }^{66}$ Wittig reaction: $90 \%$ yield $(0.4 \mathrm{mmol}$ scale $), E: Z=$ 1.5:1; Hydrogenation: $72 \%$ yield $(0.4 \mathrm{mmol}$ scale $) ;{ }^{1} \mathrm{H}$ NMR $\left(400 \mathrm{MHz}, \mathrm{CDCl}_{3}\right) \delta 7.34(2 \mathrm{H}, \mathrm{t}$, $J=7.2 \mathrm{~Hz}), 7.28-7.21(4 \mathrm{H}, \mathrm{m}), 6.85(1 \mathrm{H}, \mathrm{d}, J=7.5 \mathrm{~Hz}), 6.83-6.78(2 \mathrm{H}, \mathrm{m}), 3.83(3 \mathrm{H}, \mathrm{s})$, $2.97(4 \mathrm{H}, \mathrm{s}) ;{ }^{13} \mathrm{C} \mathrm{NMR}\left(101 \mathrm{MHz}, \mathrm{CDCl}_{3}\right) \delta 159.7,143.5,141.9,129.4,128.6,128.5,126.0$, 121.0, 114.3, 111.4, 55.2, 38.1, 37.9; HRESIMS $m / z[\mathrm{M}+\mathrm{H}]^{+} 213.1270$ (calcd for $\mathrm{C}_{15} \mathrm{H}_{17} \mathrm{O}$, 213.1274). 


\section{ASSOCIATED CONTENT}

Supporting Information. Characterization of all prepared compounds and ${ }^{1} \mathrm{H}$ NMR and ${ }^{13} \mathrm{C}$ NMR data for compounds 6 and 7. Table of terrestrial natural origin of included prepared compounds as well as organism images and discussion about the biological activities of stilbenoids. This material is available free of charge via the Internet at http://pubs.acs.org.

\section{AUTHOR INFORMATION}

\section{Corresponding Author}

* Author to whom correspondence should be addressed. Tel.: +46 706 855075; Fax: +46 33 103388; E-mail: Johan.svenson@ri.se.

\#Present address: Department of Chemistry, Umeå University, SE-901 87, Umeå, Sweden.

\section{Author Contributions}

The manuscript was written through contributions of all authors. All authors have given approval to the final version of the manuscript.

\section{ACKNOWLEDGMENTS}

This work was partly supported with grants from the Norwegian Research Council (ES508288) and J.S. and L.W.K.M. are grateful for the support. J.S was further supported by a VINNMER M.C. incoming grant from VINNOVA (grant. 2014-01435). H.P. and G.C. were supported by the Centre for Marine Chemical Ecology (http://www.cemace.science.gu.se) at the University of Gothenburg. C.H and R.T were supported by Biogenouest (http://www.biogenouest.org) at the University of Western Brittany. The authors are grateful to the New Zealand Ministry of Business, Innovation and Employment (MBIE) for 
funding the Biocide Tool Box research programme (UOAX1410), which supported P.C. involvement in this research. R.A, Ingebrigtsen (UiT The Arctic University of Norway) and J. Lehmuskallio (http://www.luontoportti.com) are acknowledged for providing the microalgae and crowberry images. The authors would also like to thank E. Raasholm for providing the comparison of juglone vs. batatasin-III interference capacity on lettuce roots and S. Kaino, E. Robertsen and C. Weber (UiT The Arctic University of Norway) for their help on the lettuce seedling experiment.

\section{REFERENCES}

Wardle, D. A.; Karban, R.; Callaway, R. M. Trends Ecol. Evol. 2011, 26, 655662.

Wardle, D. A.; Nilsson, M. C.; Gallet, C.; Zackrisson, O. Biol. Rev. 1998, 73, 305-319.

Nilsson, M. C.; Wardle, D. A. Front. Ecol. Environ. 2005, 3, 421-428.

Raven, P. H.; Evert, R. F.; Eichorn, S. E. Biology of Plants, 5 Edn.; Worth

Publishers: New York, 1992.

Yadav, R.; Agarwala, M. J. Phytol. 2011, 3, 10-14.

King, A.; Young, G. J. Am. Diet. Assoc. 1999, 99, 213-218.

Close, D. C.; McArthur, C. Oikos 2002, 99, 166-172.

Lattanzio, V.; Lattanzio, V. M.; Cardinali, A. In Phytochemistry: Advances in Research, Imperato, F., Ed.; Research Signpost: Kerala, India, 2006; Vol. 661, pp 23-67.

Xu, F. Q.; Xu, F. C.; Hou, B.; Fan, W. W.; Zi, C. T.; Li, Y.; Dong, F. W.; Liu, Y. Q.; Sheng, J.; Zuo, Z. L. Bioorg. Med. Chem. Lett. 2014, 24, 5268-5273. 

28, 3031-3034. 
Zhang, Y. F.; Zhang, H.; He, L.; Liu, C.; Xu, Y.; Qian, P. Y. ACS Chem. Biol. 2012, 7, 1049-1058.

(29) Trepos, R.; Cervin, G.; Hellio, C.; Pavia, H.; Stensen, W.; Stensvåg, K.;

Svendsen, J. S.; Haug, T.; Svenson, J. J. Nat. Prod. 2014, 77, 2105-2113.

Briand, J. F. Biofouling 2009, 25, 297-311.

Babula, P.; Vaverkova, V.; Poborilova, Z.; Ballova, L.; Masarik, M.; Provaznik, I. Plant Physiol. Biochem. 2014, 84, 78-86.

Stupak, M. E.; García, M. T.; Pérez, M. C. Int. Biodeterior. Biodegrad. 2003, $52,49-52$

Pérez, M.; Blustein, G.; García, M.; del Amo, B.; Stupak, M. Prog. Org. Coat. 2006, 55, 311-315.

Shen, T.; Wang, X. N.; Lou, H. X. Nat. Prod. Rep. 2009, 26, 916-935.

Hernández-Romero, Y.; Rojas, J. I.; Castillo, R.; Rojas, A.; Mata, R. J. Nat. Prod. 2004, 67, 160-167.

Reyes-Ramírez, A.; Leyte-Lugo, M.; Figueroa, M.; Serrano-Alba, T.; GonzálezAndrade, M.; Mata, R. Eur. J. Med. Chem. 2011, 46, 2699-2708.

Kumar, P.; Guntreddi, T.; Singh, R.; Singh, K. N. Org. Chem. Front 2017, 4, 147-150.

Hernández-Romero, Y.; Acevedo, L.; de Los Ángeles Sánchez, M.; Shier, W.

T.; Abbas, H. K.; Mata, R. J. Agric. Food Chem. 2005, 53, 6276-6280.

Trepos, R.; Cervin, G.; Pile, C.; Pavia, H.; Hellio, C.; Svenson, J. Biofouling

2015, 31, 393-403.

Guardiola, F. A.; Cuesta, A.; Meseguer, J.; Esteban, M. A. Int. J. Mol. Sci. 2012, $13,1541-1560$.

Konstantinou, I.; Albanis, T. Environ. Int. 2004, 30, 235-248. 
Hanssen, K. Ø.; Cervin, G.; Trepos, R.; Petitbois, J.; Haug, T.; Hansen, E.;

Andersen, J. H.; Pavia, H.; Hellio, C.; Svenson, J. Mar. Biotechnol. 2014, 16, 684-694.

Moodie, L. W. K.; Trepos, R.; Cervin, G.; Larsen, L.; Larsen, D. S.; Pavia, H.;

Hellio, C.; Cahill, P. L.; Svenson, J. J. Nat. Prod. 2017, 80, 515-525.

Müller, W. E.; Wang, X.; Proksch, P.; Perry, C. C.; Osinga, R.; Gardères, J.;

Schröder, H. C. Mar. Biotechnol. 2013, 15, 375-398.

Schultz, M. P. Biofouling 2007, 23, 331-341.

Bixler, G. D.; Bhushan, B. Phil. Trans. Roy. Soc. A. 2012, 370, 2381-2417.

Almeida, J. R.; Vasconcelos, V. Biotechnol. Adv. 2015, 33, 343-357.

Sjögren, M.; Göransson, U.; Johnson, A. L.; Dahlström, M.; Andersson, R.;

Bergman, J.; Jonsson, P. R.; Bohlin, L. J. Nat. Prod. 2004, 67, 368-372.

Ortlepp, S.; Sjögren, M.; Dahlström, M.; Weber, H.; Ebel, R.; Edrada, R.;

Thoms, C.; Schupp, P.; Bohlin, L.; Proksch, P. Mar. Biotechnol. 2007, 9, 776785.

Wang, C. Y.; Wang, K. L.; Qian, P. Y.; Xu, Y.; Chen, M.; Zheng, J. J.; Liu, M.;

Shao, C. L.; Wang, C. Y. AMB Expr. 2016, 6, 1-10.

Cahill, P.; Heasman, K.; Jeffs, A.; Kuhajek, J.; Mountfort, D. Biofouling 2012, $28,39-49$.

Cahill, P. L.; Atalah, J.; Selwood, A. I.; Kuhajek, J. M. PeerJ 2016, 4, 1-18.

Brännäs, E.; Nilsson, M. C.; Nilsson, L.; Gallet, C.; Brännäs, K.; Berglind, R.;

Eriksson, L. O.; Leffler, P. E.; Zackrisson, O. J. Chem. Ecol. 2004, 30, 215-227.

Hogetsu, K.; Okanishi, R.; Sugawara, H. Jap. J. Limnol. 1960, 21, 124-130.

Nakai, S.; Inoue, Y.; Hosomi, M.; Murakami, A. Water Sci. Technol. 1999, 39, 47-53. 
Nakai, S.; Inoue, Y.; Hosomi, M.; Murakami, A. Water Res. 2000, 34, 30263032.

(57) Chalal, M.; Vervandier-Fasseur, D.; Meunier, P.; Cattey, H.; Hierso, J. C. Tetrahedron 2012, 68, 3899-3907.

(58) Nawrat, C. C.; Palmer, L. I.; Blake, A. J.; Moody, C. J. J. Org. Chem. 2013, 78, 5587-5603.

(59) Han, S. Y.; Lee, H. S.; Choi, D. H.; Hwang, J. W.; Yang, D. M.; Jun, J. G. Synthetic Commun. 2009, 39, 1425-1432.

(60) Chambers, L. D.; Hellio, C.; Stokes, K.; Dennington, S.; Goodes, L.; Wood, R.; Walsh, F. Int. Biodeterior. Biodegrad. 2011, 65, 939-946.

(61) Jellali, R.; Campistron, I.; Pasetto, P.; Laguerre, A.; Gohier, F.; Hellio, C.;

Pilard, J. F.; Mouget, J. L. Prog. Org. Coat. 2013, 76, 1203-1214.

(62) Berntsson, K. M.; Jonsson, P. R.; Lejhall, M.; Gatenholm, P. J. Exp. Mar. Biol. Ecol. 2000, 251, 59-83.

(63) Thabard, M.; Gros, O.; Hellio, C.; Maréchal, J. P. Bot. Mar. 2011, 54, 147-157.

(64) Sonak, S.; Bhosle, N. B. Biofouling 1995, 9, 31-38.

(65) Systat Software Inc. SigmaPlot, Systat Software Inc.: San Jose, CA, 2015.

(66) Blangetti, M.; Fleming, P.; O'Shea, D. F. J. Org. Chem. 2012, 77, 2870-2877. 
TABLE OF CONTENT GRAPHIC
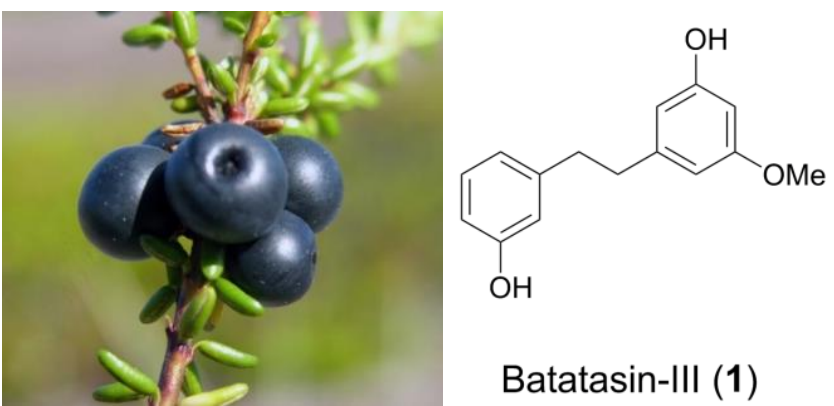

Batatasin-III (1) 